\title{
Foreword: entrepreneurship and global growth
}

What the world needs now is jobs. Although global population growth is slowing, the exceptionally large cohorts born during the 1980s and 1990s - years of high fertility in most countries of the world - are now ready to join the labor market. Thus, we are still in the midst of a labor force boom not likely to end for another 30 or 40 years.

Moreover, this is happening unevenly in different regions of the globe. In the developed world, the population in the 15-59 age group - the prime labor force years - is declining, and the labor force in the developed countries is expected to decline by almost 10 percent between 2010 and 2040. At the same time, the labor force in the developing world is still rising rapidly and is expected to increase by one-third by 2050 . This excludes China, whose labor force will stop growing and start to decline from 2015, falling by 140 million by 2040 . Rather, it is the still high fertility countries that will see a future labor boom. In the least developed countries - the 'bottom billion' of the world's population - the labor force is projected to double during this same time span.

In sub-Saharan Africa alone, the population aged 15-59 will increase from 450 million today to nearly 1.2 billion by 2050 . Thus, essentially all of the growth in the world's labor force in the coming decades will occur in the less developed countries, again excluding China. In these societies, the number of 15- to 59-year-olds will rise by 1.2 billion in the next 40 years. This leads to the question of how many jobs they will need to create and how fast.

These diverse trends are shown in Figure 1.

The world clearly stands on a precipice. With the number of workers in the developed world set to begin an unprecedented decline and the number in poorer nations rapidly increasing, global economic growth depends on putting the workforces of the developing nations into productive jobs. If those jobs do not appear, the massive potential labor force in the developing world will face high levels of unemployment or low-productivity work. Their frustration will likely spill over into radicalism and political protest, creating a wave of chaos across the world.

We have just seen one such wave spill across the Middle East and North Africa, with revolts and revolutions breaking out from Morocco to Oman, and leading to civil war in Libya. Although economies across the region have grown in recent years, the gains bypassed the majority of the population. Instead of growing jobs and wages, the benefits of economic growth were amassed by a wealthy few, leaving vast portions of the population mired in abject poverty.

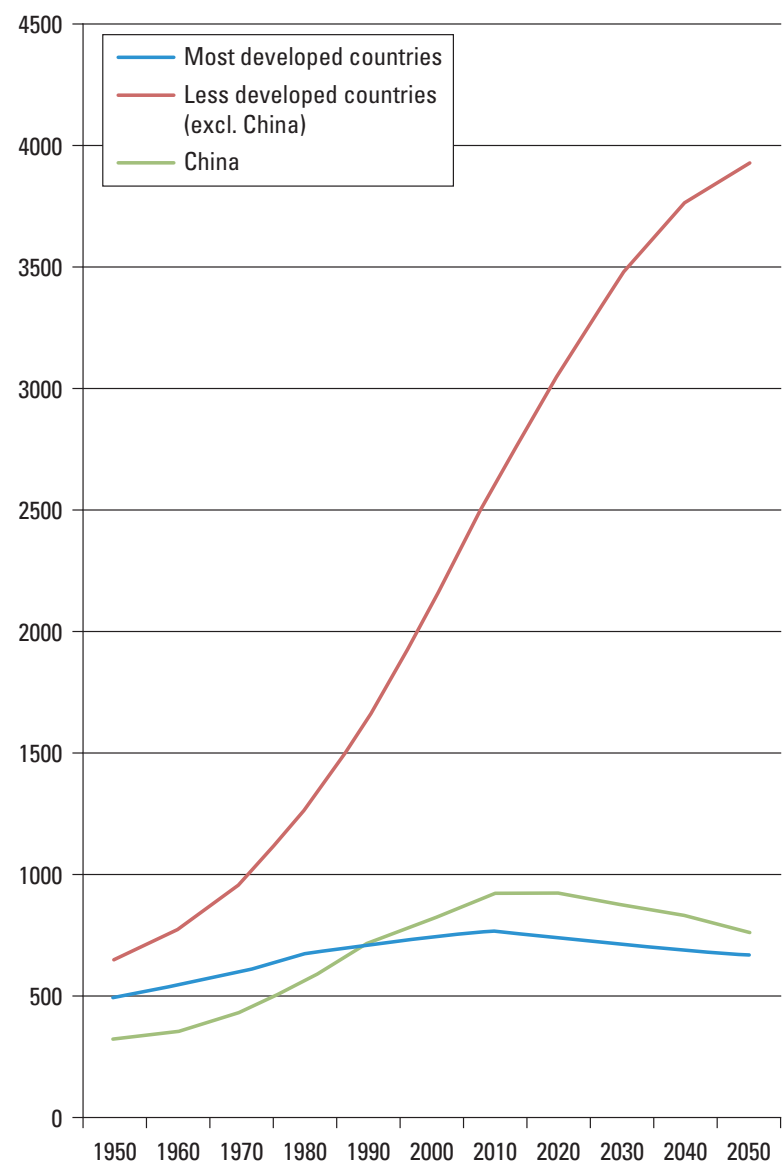

Figure 1 Labor force growth (population age 15-59, in 000s; UN 2011 medium variant projection)

A major driver of unrest in the Middle East has been the shortage of jobs even for the educated, and low and stagnant wages for most workers. This has stemmed in part from the surge in the Arab world's young population. The percentage of young adults - those aged 15 to 29 as a fraction of all those over 15 - ranges from 38 percent in Bahrain and Tunisia to over 50 percent in Yemen (compared to 26 percent in the United States). Not only is the proportion of young people in the Middle East extraordinarily high, but their numbers have grown quickly over a short period of time. Since 1990, the youth population (those aged 15-29) has grown by 50 percent in Libya and Tunisia, 65 percent in Egypt, and 125 percent in Yemen.

This youth surge has not only clogged the lower ranks of the job ladder, where more than 40 percent of Egyptians struggle on less than $\$ 2$ per day. Thanks to the modernization policies of their governments, college 
enrollment has soared across the region in the last quarter century, more than tripling in Tunisia, quadrupling in Egypt, and expanding tenfold in Libya.

It would be difficult, if not impossible, for any government to create enough jobs to keep pace. For many Middle Eastern regimes, the problem has been especially difficult to manage, as Arab socialist governments, beginning with Gamal Nasser in the 1950s, had guaranteed state jobs for college graduates. This led many people to look at a college degree as providing an entitlement to state employment - the opposite of the entrepreneurial spirit. Instead of a vibrant private sector with expanding employment, these countries typically had a massive state sector that concentrated wealth in the hands of close associates of the government. The state sector kept the peace by providing mass employment for decades, but the recent surge in youth and college graduates simply overwhelmed this strategy. From the 1990s, to keep a fiscal balance, governments across the region gave up the promise of state jobs for all college graduates. Moreover, Middle Eastern governments also reduced the safety nets of extensive subsides for staple foods and fuel.

Yet with youth looking mainly for state jobs, and vocational training grossly inadequate, the result was incredibly high youth unemployment across the region. According to the International Labor Organization, youth unemployment in the Middle East and North Africa reached 23 percent, or twice the global average, in 2008. Moreover, unemployment among the educated has been even worse: in Egypt, college graduates are 10 times as likely to have no job as those with only an elementary school education.

In many developing economies, the informal sector provides an outlet for the unemployed, and a channel for entrepreneurial efforts. Yet in the Middle East, exceptionally intrusive governments made even that pathway difficult. The regional wave of protests was sparked by the self-immolation of Mohamed Bouazizi, a 26-year-old Tunisian man unable to find formal work, whose fruit cart was confiscated by the police. Having faced a history of bullying, petty fines and confiscations, and humiliation by the authorities simply for seeking to support his family by his efforts in the informal sector, Bouazizi's frustration boiled over and he displayed his anger and frustration by publicly setting himself ablaze. His frustration had echoes with millions throughout the region who had faced similar frustrations and humiliations seeking work, and his fire ignited a blaze of revolts that toppled his government and that of Egypt, and has put other regimes throughout the region on the defensive.

How can more than one billion jobs be created in the developing world within the next four decades, especially in the least developed countries, where poverty, corruption and massive unemployment are already the dominant facts of economic life? The approaches used by the development community in the last 50 years have generally not been effective. Simply making capital more readily available in the form of grants and loans had created debt and squandered resources. Building roads, dams and power stations with the idea that if rich countries build them, jobs will come, also proved a misguided hope. More recent approaches, such as microcredit, improving the rule of law, and supporting smallholder property registration, all of which were aimed at jump-starting the formation of small businesses, have helped in many localities, but they have yet to produce the increase in large-scale, labor-intensive industries that will be required to provide jobs where they are most needed.

The one solution that can provide jobs on that scale lies in a combination of innovation and entrepreneurship. The research on economic growth over the last 30 years has strongly emphasized that rapid job creation comes from rapidly growing companies. Therefore, only by founding fast-growing new companies that provide new products or services that are widely desired will today's developing countries be able to provide the jobs sought by their still rapidly growing populations. Most such companies are created by exploiting new market niches and offering novel products, services or processes that have few competitors or substitutes. The combination of having novel products, few immediate competitors, and the high demand created by new markets can sustain high levels of profitability, which will provide the capital and the incentives for the rapid expansion of production and employment. ${ }^{1}$

Some economists believe that developing economies should exploit their comparative advantages in low-cost labor and the production of primary products, while advanced economies function as the sites of technical innovation and entrepreneurship that create new industries. However, this approach has not been, and will not be, sufficient to lift the developing world and meet its employment challenges. Competing with low-cost labor was effective when the rich world seemed to be able to absorb an unending stream of cheap imports, and only a few nations actually followed this path. This strategy will hardly work when a billion new workers are looking for employment while the economies of the rich world aging and paying down their accumulated debts - are shifting from rapid to tepid growth. Moreover, relying on the production of primary product condemns countries to endless cycles of commodity boom and bust - as countries from Russia to Zambia have discovered, to their great sorrow. To sell into the rapidly growing markets of the emerging nations will require new products for these new markets that are cheaper, easier to maintain and vastly more efficient. Only innovation and the creation of new enterprises are likely to offer a long-term solution to the economic needs of developing countries.

If the key to future global economic growth is the spread of innovation and entrepreneurship in the developing world, how can that spread be encouraged? The first steps are to determine the conditions that favor 
entrepreneurship, devise a way to measure them, and then assess the gaps and improvements needed in each country. That is what the Global Entrepreneurship and Development Index can now provide for the developing world.

Jack Goldstone

Virginia E. and John T. Hazel Jr Professor George Mason University, VA, USA

\section{Note}

1. Ács (2002); Ács and Armington (2006); Audretsch et al. (2006); Ács et al. (2009); Braunerhjelm et al. (2010); and McCann and Ács (2011).

\section{References}

Ács, Z.J. (2002), Innovation and the Growth of Cities, Cheltenham, UK and Northampton, MA, USA: Edward Elgar.

Ács, Z.J. and C. Armington (2006), Entrepreneurship, Geography, and American Economic Growth, Cambridge: Cambridge University Press.

Ács, Z.J., P. Braunerhjelm, D. Audretsch and B. Carlsson (2009), 'The knowledge spillover theory of entrepreneurship', Small Business Economics, 32(1), 15-30.

Audretsch, D.B., M.C. Keilbach and E. Lehmann (2006), Entrepreneurship and Economic Growth, Oxford: Oxford University Press.

Braunerhjelm, P., Z.J. Ács and B. Carlsson (2010), 'The missing link: knowledge diffusion and entrepreneurship in endogenous growth', Small Business Economics, 34(1), 105-25.

McCann, P. and Z.J. Ács (2011), 'Globalization: countries, cities and multinationals', Regional Studies, 45(1), 17-32. 